Supporting Information

\title{
Activatable Photosensitizer for Smart Photodynamic Therapy Triggered by Reactive Oxygen Species in Tumor Cells
}

\author{
Bin Yuan, Hua Wang, Jiang-Fei Xu*, Xi Zhang \\ E-mail: xujf@mail.tsinghua.edu.cn \\ Key Lab of Organic Optoelectronics and Molecular Engineering, Department of \\ Chemistry, Tsinghua University, Beijing 100084, People's Republic of China
}


1. Synthesis of BODIPY 1, BODIPY-2I, ProBODIPY and ProBODIPY-2I

2,4-Dimethylpyrrole $(1.2 \mathrm{~mL}, 12 \mathrm{mmol})$ and 4-pyridinecarboxaldehyde $(535 \mathrm{mg}$, 
$5 \mathrm{mmol}$ ) were dissolved in $600 \mathrm{~mL}$ anhydrous dichloromethane under $\mathrm{Ar}$ atmosphere. Trifluoroacetic acid $(60 \mu \mathrm{L}, 0.8 \mathrm{mmol})$ was added by syringe as catalyst. The mixture was stirred overnight at ambient temperature. Then 2,3Dichloro-5,6-dicyano-1,4-benzoquinone $(1.1 \mathrm{~g}, 5 \mathrm{mmol})$ was added into the reaction mixture and stirred for $1 \mathrm{~h}$. Triethylamine $(12 \mathrm{~mL})$ and boron trifluoride diethyl etherate $(12 \mathrm{~mL})$ were added and the reaction was stirred for another 3 h. The mixture was quenched and washed with saline for three times. The organic phase was dried by $\mathrm{Na}_{2} \mathrm{SO}_{4}$ and removed by rotary evaporator. The product was obtained by column chromatography with eluent of DCM, followed by recrystallization from solution of PE/DCM ( $v / v, 1: 9)$, giving wine solid (200 mg, 12.3\%). ${ }^{1} \mathrm{H} \mathrm{NMR}\left(\mathrm{CDCl}_{3}, 400 \mathrm{MHz}\right): \mathrm{d}=8.77$ (d, $2 \mathrm{H}$, pyridine $\left.\mathrm{H}\right), 7.30(\mathrm{~d}$, $2 \mathrm{H}$, pyridine $\mathrm{H}), 6.00(\mathrm{~s}, 2 \mathrm{H}$, pyrrole $\mathrm{H}), 2.55\left(\mathrm{~s}, 6 \mathrm{H}, \mathrm{CH}_{3}\right), 1.40\left(\mathrm{~s}, 6 \mathrm{H}, \mathrm{CH}_{3}\right)$. MS-ESI(m/z): Calcd for $\mathrm{C}_{18} \mathrm{H}_{18} \mathrm{BF}_{2} \mathrm{~N}_{3}: 325.16$, found $[\mathrm{M}+\mathrm{H}]+: 326.16$

BODIPY 1 (200 mg, $0.62 \mathrm{mmol}$ ) and 4-(bromomethyl) benzeneboronic acid pinacol ester $(1.5 \mathrm{~g}, 5.01 \mathrm{mmol})$ were dissolved in DCM and stirred at room temperature overnight. The reaction mixture was dropwise added into diethyl ether and the participant was filtered and washed with diethyl ether, giving an orange solid(144 mg, 43.2\%) ${ }^{1} \mathrm{H}$ NMR(DMSO, $400 \mathrm{MHz}$ ): $\mathrm{d}=9.36(\mathrm{~d}, 2 \mathrm{H}$, pyridine $\mathrm{H}), 8.46(\mathrm{~d}, 2 \mathrm{H}$, pyridine $\mathrm{H}), 7.71(\mathrm{~d}, 2 \mathrm{H}, \mathrm{ArH}), 7.45(\mathrm{~d}, 2 \mathrm{H}, \mathrm{ArH}), 6.24$ (s, 2H, $\left.\mathrm{CH}_{2}\right), 6.97$ (s, pyrrole H), $2.45\left(\mathrm{~s}, 6 \mathrm{H}, \mathrm{CH}_{3}\right), 1.34\left(\mathrm{~s}, 6 \mathrm{H}, \mathrm{CH}_{3}\right), 1.26$ (s, 
12H, $\mathrm{CH}_{3}$ ). MS-ESI (m/z): Calcd for $\mathrm{C}_{31} \mathrm{H}_{36} \mathrm{~B}_{2} \mathrm{~F}_{2} \mathrm{~N}_{3} \mathrm{O}_{2}{ }^{+}: 542.30$, found: 542.30

BODIPY $1(280 \mathrm{mg}, 0.85 \mathrm{mmol}), \mathrm{HIO}_{3}(300 \mathrm{mg}, 1.70 \mathrm{mmol})$ and $\mathrm{I}_{2}(430 \mathrm{mg}$, $1.70 \mathrm{mmol})$ were added to ethanol $(20 \mathrm{~mL})$. The mixture was stirred for 3 days at ambient temperature. Thin layer chromatography was employed to monitor the conversion of reactant. Then the solvent was removed by rotary evaporator. The Product BODIPY-2I was obtained by column chromatography with eluent of $\mathrm{DCM} / \mathrm{CH}_{3} \mathrm{OH}(30: 1, v / v)$, giving a purple solid (195 mg, 39.8\%). ${ }^{1} \mathrm{H}$ NMR $\left(\mathrm{CDCl}_{3}, 400 \mathrm{MHz}\right): \mathrm{d}=8.80(\mathrm{~d}, 2 \mathrm{H}$, pyridine $\mathrm{H}), 7.27(\mathrm{~d}, 2 \mathrm{H}$, pyridine $\mathrm{H}), 2.63$ (s, $\left.6 \mathrm{H}, \mathrm{CH}_{3}\right), 1.40\left(\mathrm{~s}, 6 \mathrm{H}, \mathrm{CH}_{3}\right)$. MS-ESI (m/z): Calcd for $\mathrm{C}_{18} \mathrm{H}_{16} \mathrm{BF}_{2} \mathrm{I}_{2} \mathrm{~N}_{3}:$ : 576.95, found $[\mathrm{M}+\mathrm{H}]^{+}: 577.96$

BODIPY-2I (100 mg, $0.17 \mathrm{mmol})$ and 4-(bromomethyl) benzeneboronic acid pinacol ester $(1.2 \mathrm{~g}, 4.05 \mathrm{mmol})$ were heated in acetone nitrile at $60{ }^{\circ} \mathrm{C}$ overnight. The reaction mixture was dropwise added into diethyl ether to obtain purple participant. The product ProBODIPY-2I was filtered and washed with diethyl ether (1.2 mg, 68.7\%). ${ }^{1} \mathrm{H}$ NMR (DMSO, $400 \mathrm{MHz}$ ): $\mathrm{d}=9.45$ (d, $2 \mathrm{H}$, pyridine $\mathrm{H}), 8.49(\mathrm{~d}, 2 \mathrm{H}$, pyridine $\mathrm{h}), 7.76(\mathrm{~d}, 2 \mathrm{H}, \mathrm{ArH}), 7.50(\mathrm{~d}, 2 \mathrm{H}, \mathrm{ArH}), 6.05$ (s, 2H, CH$\left.{ }_{2}\right), 2.57\left(\mathrm{~s}, 6 \mathrm{H}, \mathrm{CH}_{3}\right), 1.38\left(\mathrm{~s}, 6 \mathrm{H}, \mathrm{CH}_{3}\right), 1.30\left(\mathrm{~s}, 12 \mathrm{H}, \mathrm{CH}_{3}\right) . \mathrm{MS}-\mathrm{ESI}$ (m/z): Calcd for $\mathrm{C}_{31} \mathrm{H}_{34} \mathrm{~B}_{2} \mathrm{~F}_{2} \mathrm{l}_{2} \mathrm{~N}_{3} \mathrm{O}_{2}{ }^{+}: 794.09$, found: 794.09 


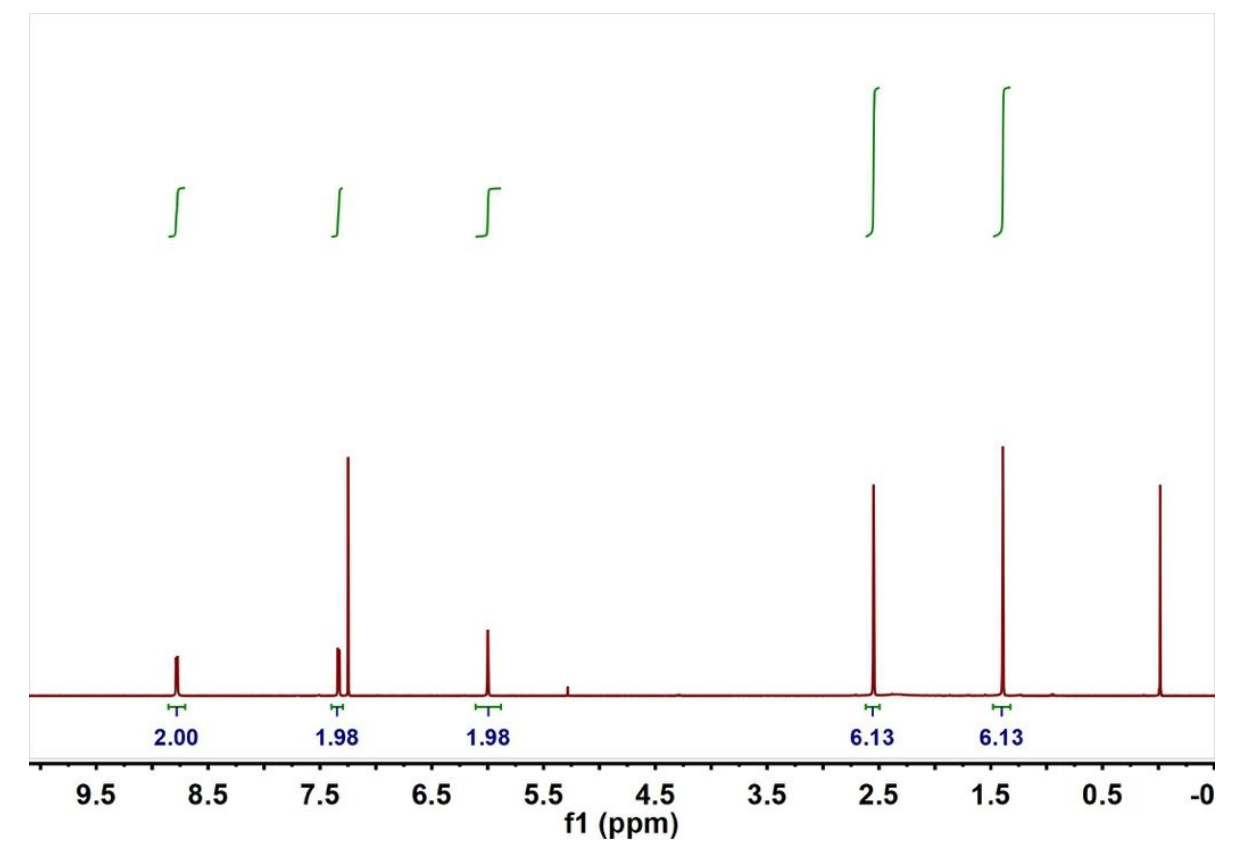

Figure S1. ${ }^{1} \mathrm{H}$ NMR spectrum of BODIPY 1

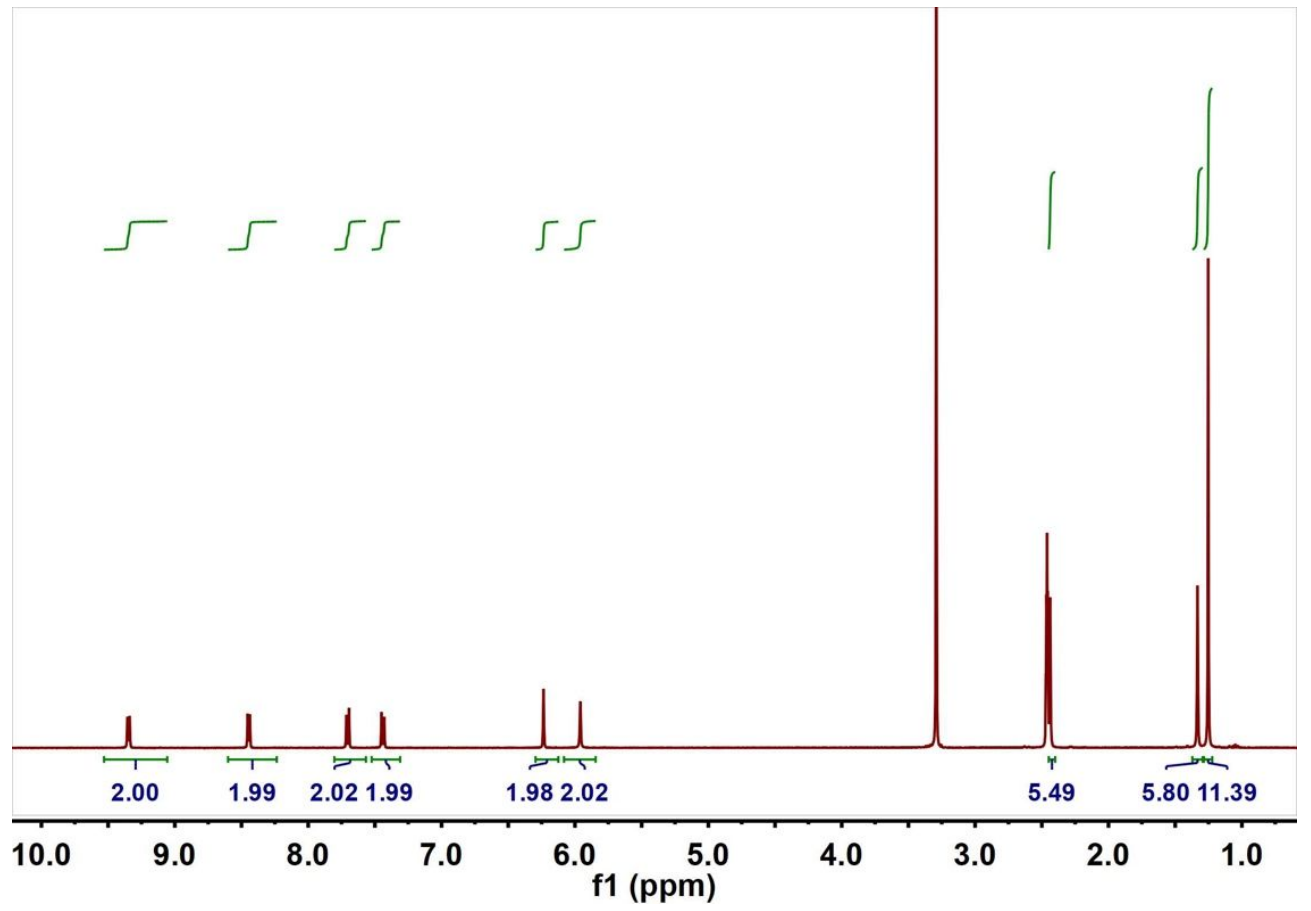

Figure S2. ${ }^{1} \mathrm{H}$ NMR spectrum of ProBODIPY 


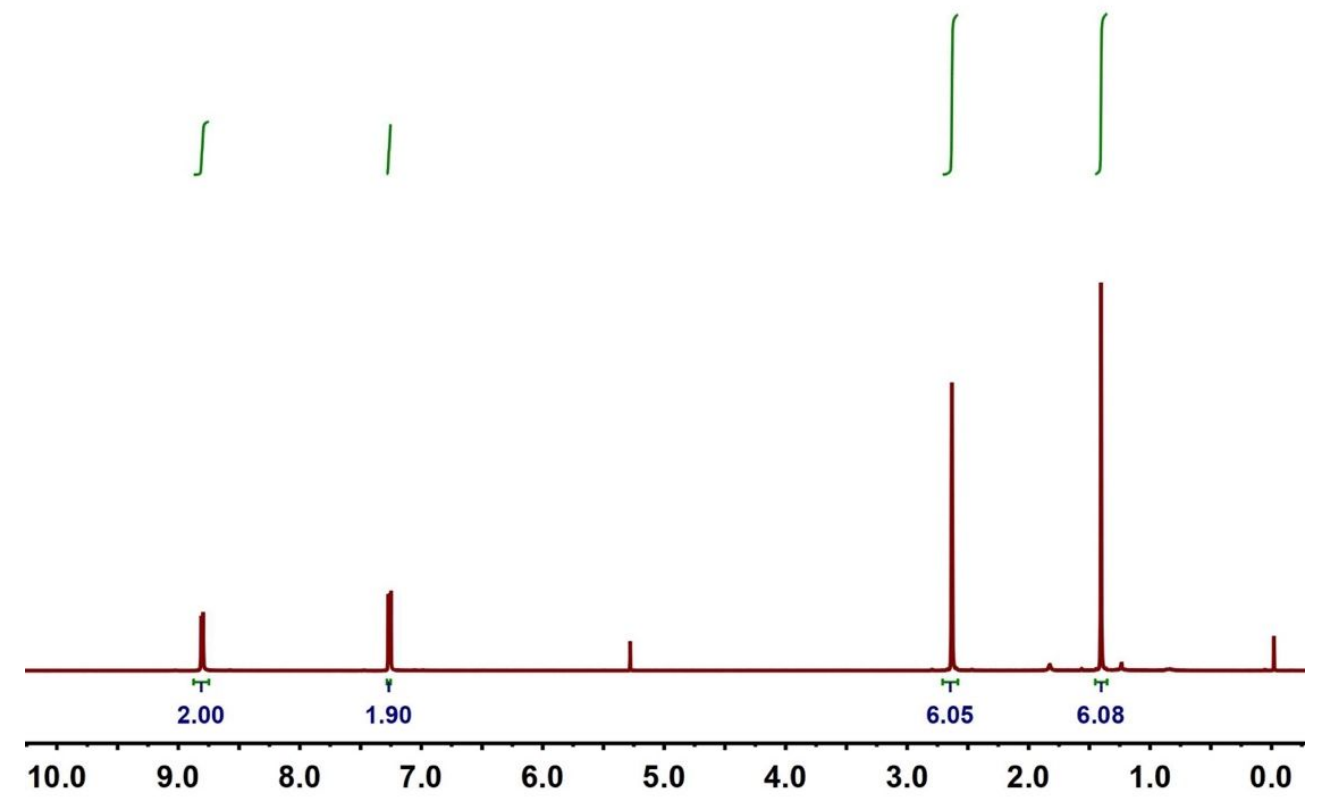

Figure S3. ${ }^{1} \mathrm{H}$ NMR spectrum of BODIPY-2I

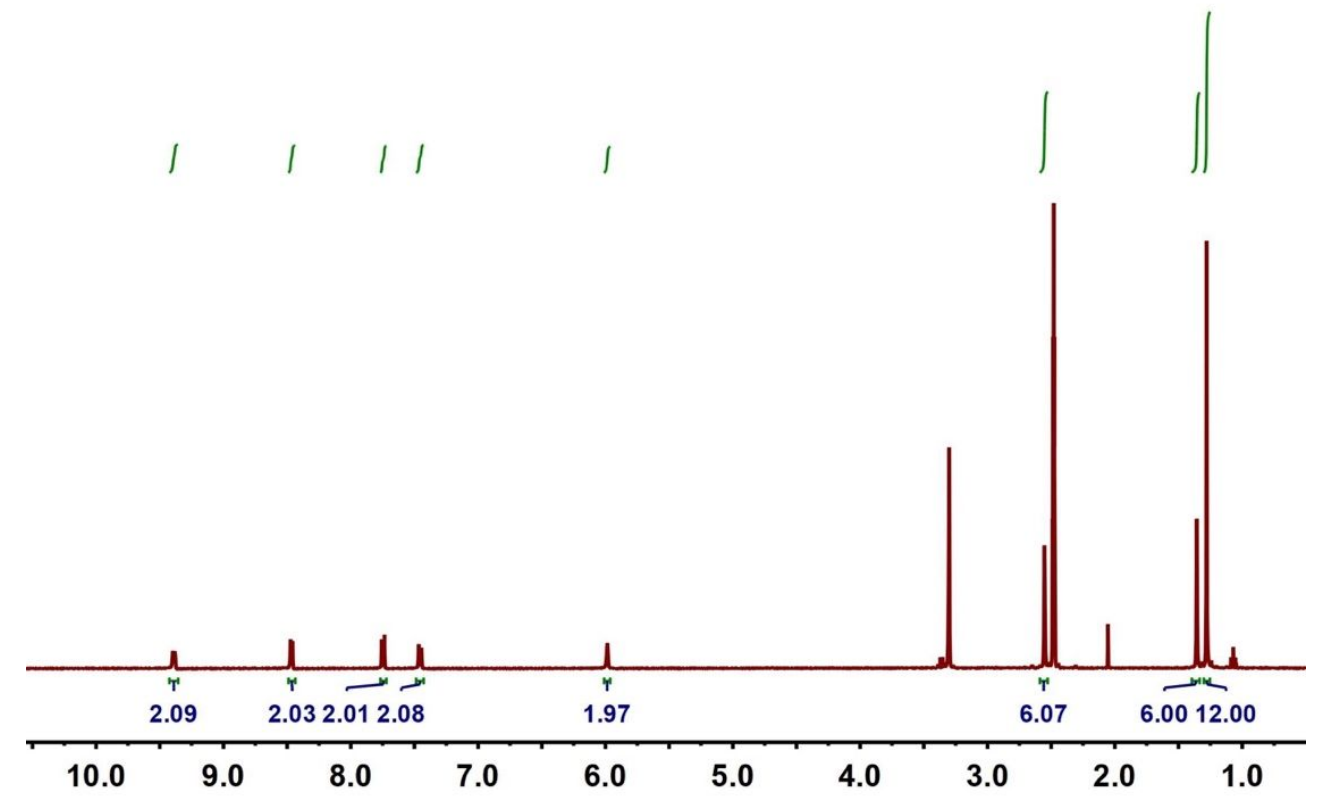

Figure S4. ${ }^{1} \mathrm{H}$ NMR spectrum of ProBODIPY-2I

2. Generation efficiency of ${ }^{1} \mathrm{O}_{2}$ measured by EPR 
2,2,6,6-tetramethyl-4-Piperidinone was dissolved in water as the probe of ${ }^{1} \mathrm{O}_{2}$. ProBODIPY-2I and BODIPY-2I were added to the solution of 2,2,6,6tetramethyl-4-Piperidinone, respectively. The as-prepared solutions were irradiated under green light and measured every 2 minutes.

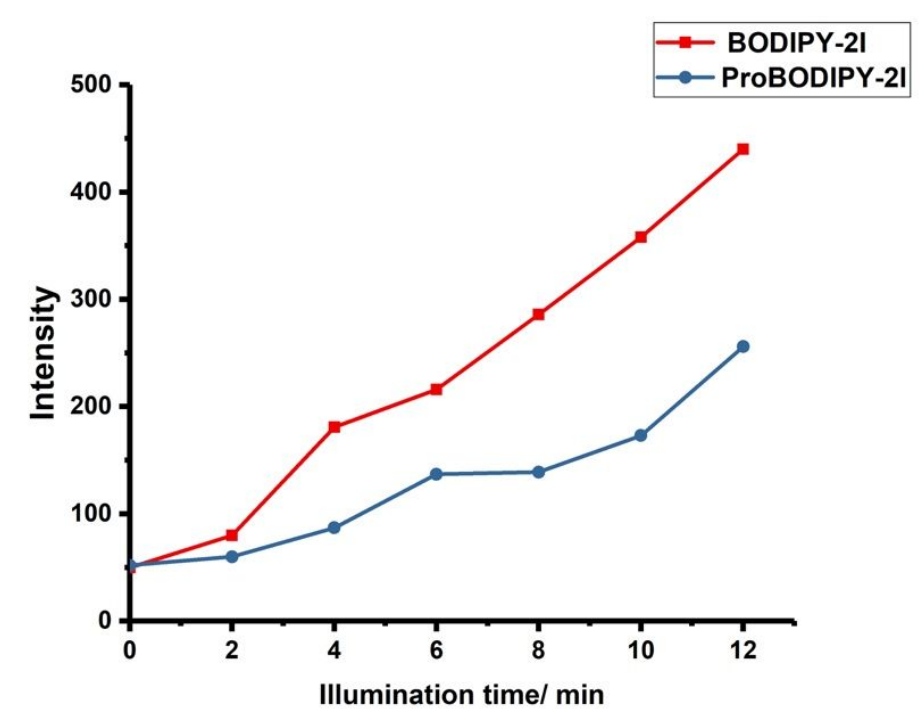

Figure S5. Generation of ${ }^{1} \mathrm{O}_{2}$ measured by EPR

\section{Stability testing of ProBODIPY-2I under light irradiation}

ProBODIPY-2I was dissolved in mixed solvent $\left(\mathrm{H}_{2} \mathrm{O} / \mathrm{CH}_{3} \mathrm{CH}_{2} \mathrm{OH}=1: 1, \mathrm{v} / \mathrm{v}\right)$ followed by irradiation under green light. UV-Vis and fluorescence spectroscopy were employed to monitor the stability of ProBODIPY-2I. Spectra were recorded every $1 \mathrm{~min}$. The excitation wavelength was $500 \mathrm{~nm}$ and the emission 
spectra were recorded from $530 \mathrm{~nm}$ to $800 \mathrm{~nm}$.
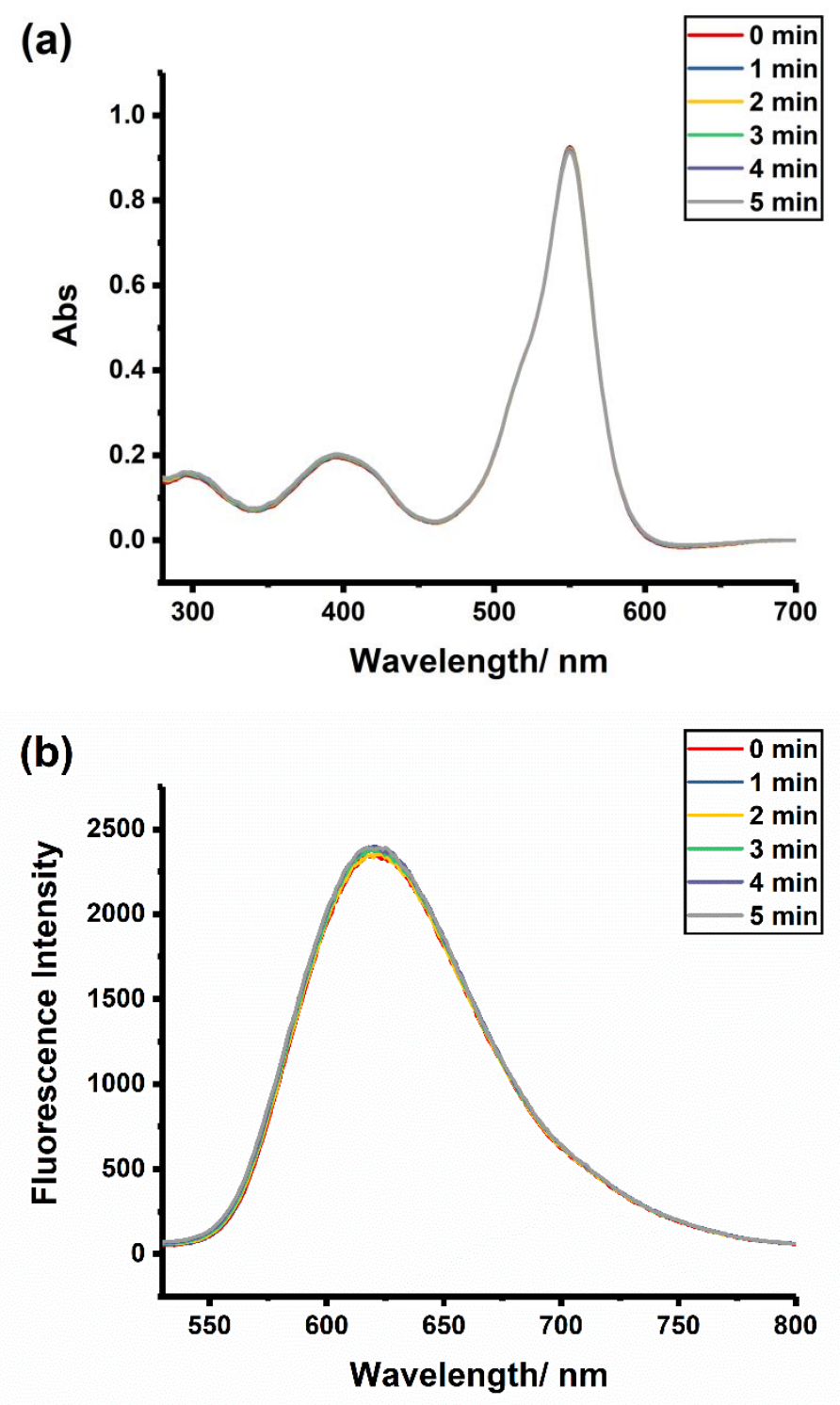

Figure S6. (a) UV-vis spectra and (b) fluorescence spectra monitoring the stability of ProBODIPY-2I under light irradiation

4. Probes used for the detection of ROS 


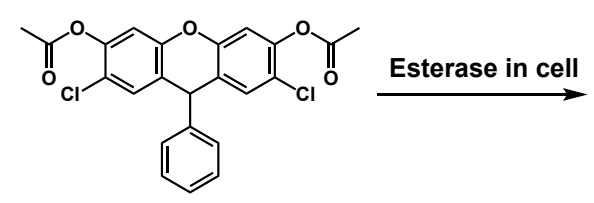

DCFH-DA

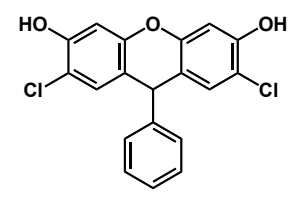

DCFH

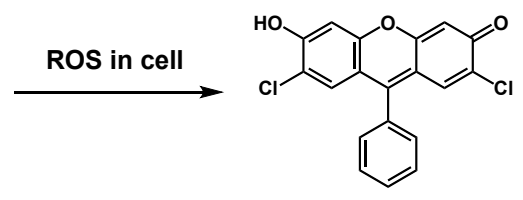

DCF

Figure S7. The mechanism of DCFH-DA for the detection of ROS<smiles>O=C([O-])CCc1c2ccccc2c(CCC(=O)[O-])c2ccccc12</smiles>

Figure S8. The mechanism of ADPA for the detection of ${ }^{1} \mathrm{O}_{2}$

5. ADPA as probe for detection of ${ }^{1} \mathrm{O}_{2}$ generated by ProBODIPY-2I and BODIPY-2I.

(a)

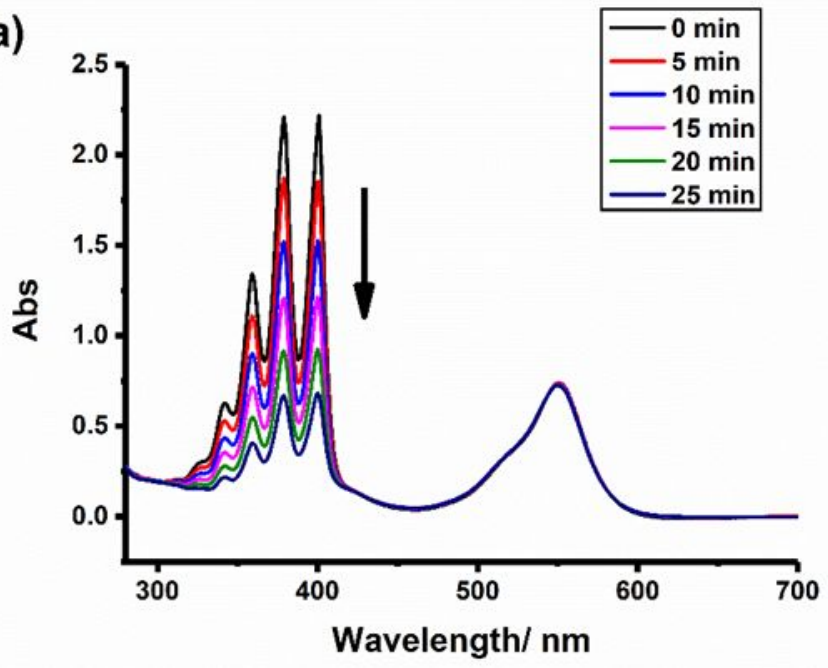



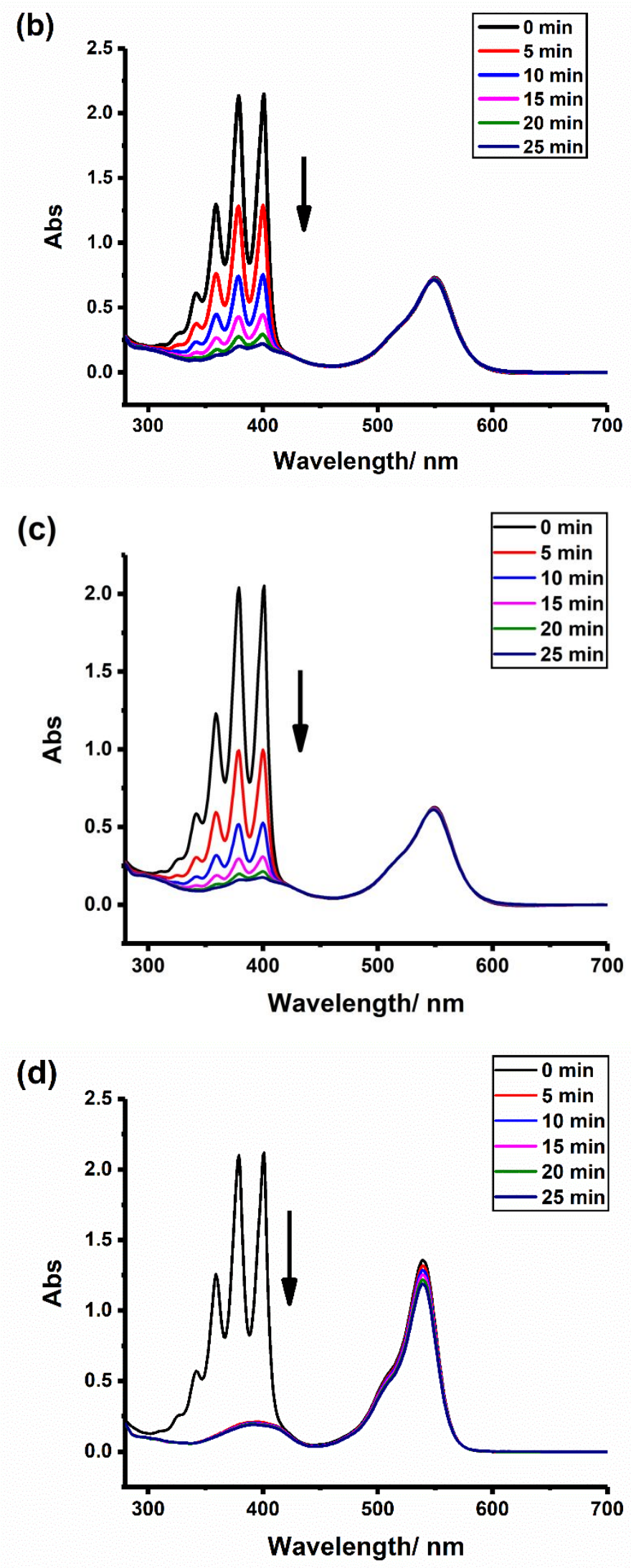

Figure S9. UV-Vis spectra of ADPA in the presence of (a) ProBODIPY-2I, (b) ProBODIPY-2I treated by $\mathrm{H}_{2} \mathrm{O}_{2}$ for $1 \mathrm{~h}$, (c) ProBODIPY-2I treated by $\mathrm{H}_{2} \mathrm{O}_{2}$ for S-10 
$3 \mathrm{~h}$ and (d) BODIPY-2I under green light irradiation.

6. Cytotoxicity of ProBODIPY-2I for human breast cancer cell MCF-7 in dark and under light irradiation

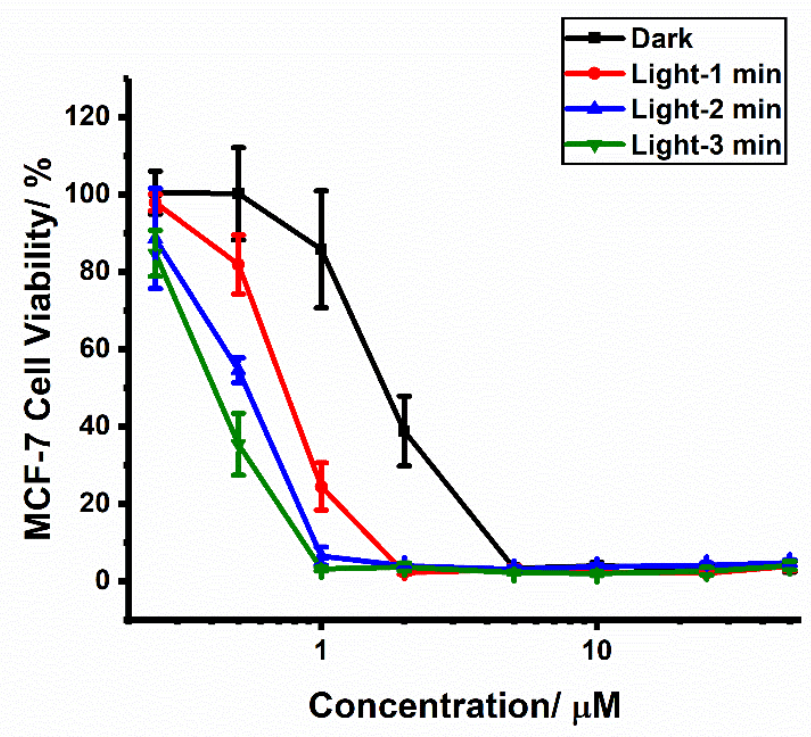

Figure S10. Cell viability MCF-7 treated with ProBODIPY-2I with or without irradiation for different time

7. Cytotoxicity of ProBODIPY for HCT116 and NCM460 


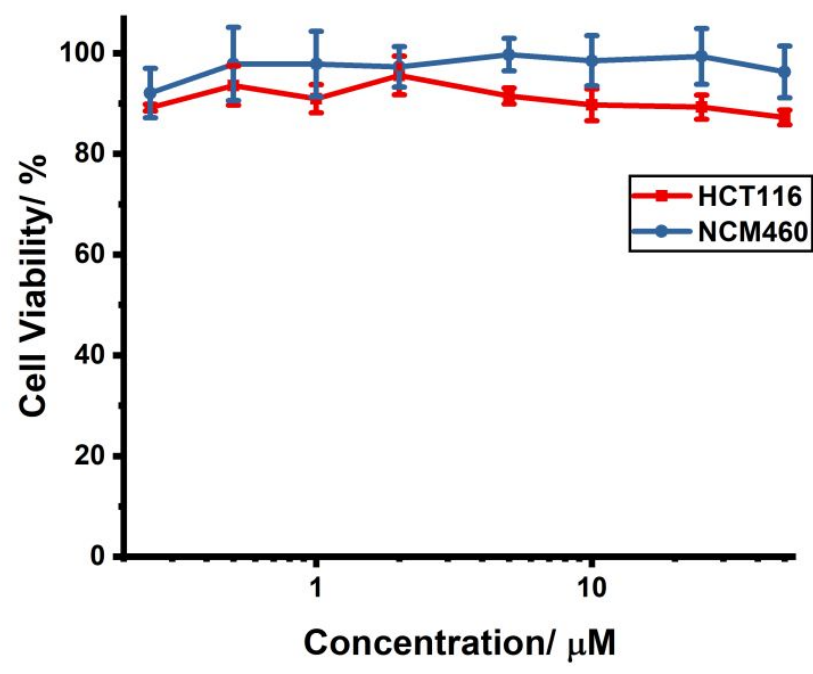

Figure S11. Cell viability HCT116 and NCM460 treated with ProBODIPY for $24 \mathrm{~h}$ 